\section{Effect of Dietary Phytase Suplementation on the Performance, Bone Densitometry, and Phosphorus and Nitrogen Excretion of Broilers}

- Author(s)
Assuena $\mathrm{V}^{1}$
Junqueira $\mathrm{OM}^{2}$
Duarte $\mathrm{KF}^{1}$
Laurentiz $\mathrm{AC}^{3}$
Filardi RS
Sgavioli $\mathrm{S}^{1}$
1 Dept of Animal Science, Universidade
Estadual Paulista Júlio de Mesquita Filho,
Faculdade de Ciências Agrárias e
Veterinárias de Jaboticabal - UNESP.
2 Dept of Animal Science, Universidade
Estadual Paulista Júlio de Mesquita Filho,
Faculdade de Ciências Agrárias e
Veterinárias de Jaboticabal - UNESP.
Dept of Biology and Animal Science,
Universidade Estadual Paulista Júlio de
Mesquita Filho, Faculdade de Engenharia
de Ilha Solteira - UNESP.

Mail Address

Vinícius Assuena

Rua Eduardo Padovani, 62 - Vila Melo

13.670-000. Santa Rita do Passa Quatro, SP, Brasil.

E-mail: viniciusassuena@yahoo.com.br

\section{Keywords}

Bone mineralization, feed conversion ratio, feed intake, weight gain.

Acknowledgements

The authors thank FAPESP for funding this study, under process n. 2005/56681-0.

\section{ABSTRACT}

This experiment was carried out to evaluate the effects of the inclusion of different levels of phytase on broiler performance, bone densitometry, and phosphorus and nitrogen excretion. Nine hundred and sixty one-day old broilers, 50\% males and 50\% females, were distributed in a completely randomized experimental design into five treatments and six replicates 32 birds each. The treatments consisted of a control diet and four diets with the addition 25,50,75, and $100 \mathrm{~g} /$ ton of phytase (250, 500, 750 and 1000 FTU of phytase/kg fed). Diets were formulated to contain equal nutritional levels, and considered the phytase product nutritional levels. In general, the addition of phytase resulted in a linear decrease in broiler performance. However, the performance results obtained with the level of $250 \mathrm{FTU}$ phytase/kg feed were not different from the control treatment. The best bone density results were observed in the control treatment, with no phytase. The results of this experiment indicate that the nutritional matrix of the phytase product needs to be reviewed when added in levels higher 250 FTU/kg to broiler diets.

\section{INTRODUCTION}

Aiming at lowering production costs, many current research studies have focused on improving the efficiency of feedstuff utilization and to reduce the impact of animal production on the environment (Payne et al., 2005).

Phosphorus is one of the most expensive nutrient of poultry and swine feeds, second only to energy and protein (Borges, 1997). It is nutritionally essential, as shown by its several roles in the body, and it is particularly important during growth. However, two thirds of the phosphorus contained in cereal grains and oil seeds are in the form of phytate, which can bind to other nutrients, rendering them unavailable for poultry and pigs, thereby, requiring dietary inorganic phosphorus supplementation (Denbow et al., 1995).

The production of industrial phytase is based on microorganisms, using DNA recombination techniques. This enzyme increases phosphorus $(P)$ availability in plant feed ingredients, where $P$ is usually present as phytate. The dietary supplementation of phytase allows poultry and pigs to more efficiently absorb phosphorus, reducing the amount of inorganic phosphorus supplementation, and promoting better weight gain, feed conversion ratio, feed intake, and bone mineralization, as well as reducing mortality (Qian et al., 1996).

Along with calcium, phosphorus has an essential role in bone formation. In the animal, phosphorus comprises about $1 \%$ of live weight, and it is carefully considered when feeds and supplements are formulated. About $80 \%$ of phosphorus in the animal body is deposited 


\section{Assuena V, Junqueira OM, Duarte KF, Laurentiz AC, Filardi RS, Sgavioli S}

in bones and teeth. Therefore, the inclusion of phytase in broiler diets may enhance their bone development.

The objectives of the present study were to evaluate the effects of the inclusion of different levels of phytase on broiler performance, bone densitometry, and phosphorus and nitrogen excretion in the litter during the starter (1 to 21 days), grower (22 to 42 days), and total (1 to 42 days) rearing phases.

\section{MATERIAL AND METHODS}

A total number of 960 ( $50 \%$ male and $50 \%$ female) Ross broilers was reared from 1 to 42 days of age in a conventional broiler house.

The experimental period was divided in three phases: starter ( 1 to 21 days of age), grower (22 to 42 days of age), and total (1 to 42 days of age) rearing periods.

A completely randomized experimental design was applied, including five treatments with six replicates of
Effect of Dietary Phytase Suplementation on the Performance, Bone Densitometry, and Phosphorus and Nitrogen Excretion of Broilers

\begin{tabular}{|c|c|c|c|c|c|c|c|c|c|c|}
\hline \multirow{3}{*}{ Ingredients (\%) } & \multicolumn{10}{|c|}{ Phytase inclusion levels(FTU/kg) } \\
\hline & \multirow[b]{2}{*}{ Control } & \multicolumn{4}{|c|}{ Starter phase } & \multirow[b]{2}{*}{ Control } & \multicolumn{4}{|c|}{ Grower phase } \\
\hline & & $250 \mathrm{FTU} / \mathrm{kg}$ & $500 \mathrm{FTU} / \mathrm{kg}$ & $750 \mathrm{FTU} / \mathrm{kg}$ & $1000 \mathrm{FTU} / \mathrm{kg}$ & & $250 \mathrm{FTU} / \mathrm{kg}$ & $500 \mathrm{FTU} / \mathrm{kg}$ & $750 \mathrm{FTU} / \mathrm{kg}$ & $1000 \mathrm{FTU} / \mathrm{kg}$ \\
\hline Corn, grain & 58.6200 & 59.8315 & 61.6810 & 62.9145 & 64.2980 & 66.0820 & 67.6155 & 69.1700 & 70.3145 & 71.4610 \\
\hline Soybean meal $45 \%$ & 35.0900 & 34.6650 & 34.0220 & 33.5930 & 33.0370 & 24.4200 & 23.8720 & 23.3210 & 23.0890 & 22.8560 \\
\hline Corn gluten $60 \%$ & 0.0000 & 0.0000 & 0.0000 & 0.0000 & 0.0000 & 3.5000 & 3.5000 & 3.5000 & 3.5000 & 3.5000 \\
\hline Soybean oil & 2.6600 & 2.0530 & 1.1410 & 0.5330 & 0.0000 & 2.8400 & 2.0800 & 1.3170 & 0.6590 & 0.0000 \\
\hline Dicalcium phosphate & 2.0300 & 1.7790 & 1.3950 & 1.1380 & 0.7540 & 1.8000 & 1.4870 & 1.1660 & 0.8440 & 0.5220 \\
\hline Limestone & 0.7200 & 0.7840 & 0.8720 & 0.9310 & 1.0180 & 0.6500 & 0.7300 & 0.8030 & 0.8750 & 0.9470 \\
\hline Vit+min premix & 0.2000 & 0.2000 & 0.2000 & 0.2000 & 0.2000 & 0.1000 & 0.1000 & 0.1000 & 0.1000 & 0.1000 \\
\hline Salt & 0.4500 & 0.4560 & 0.4560 & 0.4560 & 0.4560 & 0.4300 & 0.4290 & 0.4290 & 0.4290 & 0.4290 \\
\hline L-lysine & 0.0000 & 0.0000 & 0.0000 & 0.0000 & 0.0000 & 0.0270 & 0.0340 & 0.0410 & 0.0380 & 0.0350 \\
\hline DL-methionine & 0.2300 & 0.2290 & 0.2280 & 0.2270 & 0.2270 & 0.1510 & 0.1500 & 0.1480 & 0.1440 & 0.1400 \\
\hline Phytase & 0.0000 & 0.0025 & 0.0050 & 0.0075 & 0.0100 & 0.000 & 0.0025 & 0.0050 & 0.0075 & 0.0100 \\
\hline
\end{tabular}

32 birds each. Treatments consisted of a control diet and other four diets formulated with graded levels of the enzyme phytase $(250,500,750$, and $1000 \mathrm{FTU} / \mathrm{kg}$ feed). Phytase nutritional matrix was considered in feed formulation; therefore, all experimental diets contained the same nutritional levels as the control diet.

The experimental diets were based on corn and soybean meal, and were formulated according to the nutritional recommendations and ingredient composition described by Rostagno et al. (2005). Diet composition and nutritional levels fed during the starter ( 1 to 21 days of age) and grower ( 22 to 42 days of age) phases are presented in Tables 1 and 2, respectively.

Table 3 shows the nutritional matrix of the commercial enzyme product Natuphos ${ }^{\circledR} 10000$ for broilers, as described by the manufacturer for an inclusion of $50 \mathrm{~g}$ enzyme/ton feed, ensuring $500 \mathrm{FTU} / \mathrm{kg}$ feed.

Weight gain, feed intake and feed conversion ratio were determined for each rearing phase. At the end

Table 2 - Nutritional composition of the experimental diets of the different rearing phases.

Starter phase Control $250 \mathrm{FTU} / \mathrm{kg} 500 \mathrm{FTU} / \mathrm{kg} 750 \mathrm{FTU} / \mathrm{kg} \quad 1000 \mathrm{FTU} / \mathrm{kg}$ Control $250 \mathrm{FTU} / \mathrm{kg} 500 \mathrm{FTU} / \mathrm{kg} \mathrm{750FTU/kg} \mathrm{1000FTU/kg}$

\begin{tabular}{|c|c|c|c|c|c|c|c|c|c|c|}
\hline $\begin{array}{l}\text { Metabolizable } \\
\text { energy (kcal/kg) }\end{array}$ & 3.050 & 3.050 & 3.050 & 3.050 & 3.050 & 3.200 & 3.200 & 3.200 & 3.200 & 3.200 \\
\hline Crude protein (\%) & 21.14 & 21.14 & 21.14 & 21.14 & 21.14 & 19.00 & 19.000 & 19.000 & 19.000 & 19.000 \\
\hline Calcium (\%) & 0.897 & 0.897 & 0.897 & 0.897 & 0.897 & 0.785 & 0.785 & 0.785 & 0.785 & 0.785 \\
\hline $\begin{array}{l}\text { Available } \\
\text { phosphorus (\%) }\end{array}$ & 0.480 & 0.480 & 0.480 & 0.480 & 0.480 & 0.430 & 0.430 & 0.430 & 0.430 & 0.430 \\
\hline Sodium (\%) & 0.215 & 0.215 & 0.215 & 0.215 & 0.215 & 0.200 & 0.200 & 0.200 & 0.200 & 0.200 \\
\hline Total lysine(\%) & 1.122 & 1.122 & 1.122 & 1.122 & 1.122 & 0.900 & 0.900 & 0.900 & 0.900 & 0.900 \\
\hline Digestible lysine(\%) & 1.006 & 1.006 & 1.006 & 1.006 & 1.006 & 0.804 & 0.804 & 0.804 & 0.804 & 0.804 \\
\hline Total methionine (\%) & 0.555 & 0.555 & 0.555 & 0.555 & 0.555 & 0.470 & 0.470 & 0.470 & 0.470 & 0.470 \\
\hline Digestible methionine (\%) & 0.529 & 0.529 & 0.529 & 0.529 & 0.529 & 0.448 & 0.448 & 0.448 & 0.448 & 0.448 \\
\hline Total Met + Cys (\%) & 0.890 & 0.890 & 0.890 & 0.890 & 0.890 & 0.790 & 0.790 & 0.790 & 0.790 & 0.790 \\
\hline Digestible Met + Cys (\%) & 0.829 & 0.829 & 0.829 & 0.829 & 0.829 & 0.739 & 0.739 & 0.739 & 0.739 & 0.739 \\
\hline Total tryptophan (\%) & 0.263 & 0.263 & 0.263 & 0.263 & 0.263 & 0.209 & 0.209 & 0.209 & 0.209 & 0.209 \\
\hline Digestible tryptophan (\%) & 0.237 & 0.237 & 0.237 & 0.237 & 0.237 & 0.188 & 0.188 & 0.188 & 0.188 & 0.188 \\
\hline
\end{tabular}

${ }^{1}$ Natuphos $^{\circledR}$ 10000: commercial brand of the company BASF S/A: Estr. Samuel Aizemberg, 1707 - Bloco C - 2. Andar, São Bernardo do Campo - SP - CEP: 09851-550 


\section{Assuena V, Junqueira OM, Duarte KF, Laurentiz AC, Filardi RS, Sgavioli S}

Effect of Dietary Phytase Suplementation on the Performance, Bone Densitometry, and Phosphorus and Nitrogen Excretion of Broilers of the experimental period (42 days of age) production efficiency index (PEI = [daily weight gain $(\mathrm{g}) \times \mathrm{L}(\%)] /$ (feed conversion ratio $\times 10))$ and livability $(L(\%)=[$ total number of birds - (number of dead + culled birds)/total number of birds]) were calculated.

\begin{tabular}{lc}
\hline \multicolumn{2}{l}{ Table 3 - Nutritional matrix of phytase Natuphos ${ }^{\circledR 10000 . ~}$} \\
\hline Nutrients & Amount \\
\hline Metabolizable energy (kcal/kg) & $1,060,000$ \\
Crude protein (\%) & 4,500 \\
Calcium (\%) & 2,000 \\
Total phosphorus (\%) & 2,300 \\
Digestible lysine (\%) & 240 \\
Digestible methionine (\%) & 20 \\
Digestible cystine (\%) & 60 \\
Digestible Met+Cys (\%) & 80 \\
Digestible tryptophan (\%) & 60 \\
Digestible threonine (\%) & 260 \\
Digestible valine (\%) & 316 \\
Digestible isoleucine (\%) & 240 \\
Digestible leucine (\%) & 416 \\
Digestible arginine (\%) & 274 \\
Digestible phenylalanine (\%) & 274 \\
Digestible histidine (\%) & 118 \\
\hline
\end{tabular}

At the end of each experimental phase, ten birds per treatment were sacrificed for the collection of the tibiotarsal bone. After removing soft tissues and ligaments, the bones were radiographed for bone densitometry determination. A penetrometer or 12degree aluminum scale (alloy 6063, ABNT) was used as densitometry reference in the radiographs.

Densitometry readings were carried out after radiographic images were digitalized in appropriate scanner. Data were stored using the "Image-Pro Plus Media Cybernetics" software program, version 4.1. Readings are expressed in aluminum millimeters $(\mathrm{mm}$ Al), according to Louzada (1994).

At 35 days of age, two birds per replicate were transferred to metabolic cages and submitted to a completely randomized experimental design that included the same treatments described above. Total excreta collection method was used. The metabolism essay was carried out during eight days, with three days of adaptation to the experimental diets, and five days of excreta collection.

After collection, excreta was frozen, and subsequently processed according to Silva (1990) to obtain samples for analyses. Phosphorus and nitrogen fecal contents were determined by Fatec S/A laboratory.

The obtained results were submitted to analysis of variance using the General Linear Model (GLM) procedure of SAS software package (SAS, Institute, 2002). When significant effects $(p<0.05)$ were determined by the analysis of variance, linear and quadratic polynomial regression analyses were carried out, and the test of Tukey at $5 \%$ probability was performed when significant linear effects were detected.

\section{RESULTS AND DISCUSSION}

Table 4 shows performance parameter means for the phase of 1-21 days of age. There was a linear effect of phytase levels $(p<0.01)$ on weight gain $(y=$ 720.0847-0.0592x; $\left.R^{2}=98.29\right)$ and feed conversion ratio $\left(y=1.4161+0.0001 x ; R^{2}=99.32\right)$, indicating that with increasing dietary phytase levels, performance declined, and that an optimal phytase levels were not achieved for these parameters in the present experiment. The test of Tukey at $5 \%$ probability showed a negative effect on weight gain of levels of $750 \mathrm{FTU}$ phytase/kg feed or higher. The addition of 1000 FTU de phytase/kg feed resulted in the worst feed conversion ratio. Only feed intake was not affected by phytase inclusion levels ( $p>0.05)$.

\begin{tabular}{|c|c|c|c|}
\hline & prmance $p$ & ers from & 21 days of age \\
\hline Treatments & $W G(g)^{2}$ & $\mathrm{FI}(\mathrm{g})$ & $\mathrm{FCR}(g / g)^{3}$ \\
\hline Control & $718 \mathrm{~A}$ & 1017 & $1.417 \mathrm{C}$ \\
\hline $250 \mathrm{FTU} / \mathrm{kg}$ & $710 \mathrm{~A}$ & 1026 & $1.444 \mathrm{BC}$ \\
\hline $500 \mathrm{FTU} / \mathrm{kg}$ & $688 A B$ & 1005 & $1.462 \mathrm{BC}$ \\
\hline $750 \mathrm{FTU} / \mathrm{kg}$ & $676 \mathrm{~B}$ & 1007 & $1.490 \mathrm{AB}$ \\
\hline $1000 \mathrm{FTU} / \mathrm{kg}$ & $661 \mathrm{~B}$ & 1005 & $1.521 \mathrm{~A}$ \\
\hline F value ${ }^{1}$ & $8.46 * *$ & $0.60 \mathrm{~ns}$ & $11.79 * *$ \\
\hline$C V(\%)$ & 2.88 & 2.83 & 1.96 \\
\hline
\end{tabular}

Means followed by different letters in the same column are significantly different $(p<0.05)$ by the test of Tukey. 1 - ns - not significant $; * *$ - significant $(p<0.01) .2$ Linear effect of phytase level: $y=720.0847-0.0592 x$; $\left(R^{2}=98.29\right) .3$ Linear effect of phytase level: $y=1.4161+0.0001 x ;\left(R^{2}=99.32\right)$

The results of the present experiment are not consistent with those obtained by Murata et al. (2006), who added 750 and 1000 FTU phytase/kg feed and considered phytase matrix nutritional values, but did not observe any significant effects on broiler performance during the starter phase. However, it must be noted that those authors did not present the composition of the nutritional matrix used in their trial.

Conte et al. (2003) worked with the inclusion of 15\% rice bran and four phytase levels for starter broilers, and observed that feed intake and live weight increased with enzyme inclusion, whereas feed conversion ratio was not influenced by the studied factors. 


\section{Assuena V, Junqueira OM, Duarte KF, Laurentiz AC, Filardi RS, Sgavioli S}

Using low available phosphorus levels and phytase inclusion, Persia \& Saylor (2006) showed that phytase improved the performance of 8- to 22-day-old broilers, as opposed to Angel et al. (2006), who did not find any broiler performance differences during the starter phase when adding phytase to low available phosphorus diets.

Table 5 shows performance parameter means for the phase of 22-42 days of age. The results obtained were similar to those of the starter phase, again with no effect of phytase dietary inclusion levels on feed intake $(p>0.05)$. There were linear effects $(p<0.01)$ of phytase on weight gain $\left(y=1621.2943-0.0869 x ; R^{2}=\right.$ 85.82 ) and feed conversion ratio $(y=2.0330+$ $\left.0.000058 x ; R^{2}=94.54\right)$, with worse results in the evaluated parameters as phytase inclusion levels increased, and an optimal phytase level was again not achieved for these parameters. The test of Tukey at $5 \%$ de probability showed a negative effect of phytase dietary inclusion of 500 FTU/kg feed and higher on feed conversion ratio as compared to the control treatment, with the worst result obtained with the inclusion of $1000 \mathrm{FTU}$ phytase/kg feed $(\mathrm{p}<0.01)$. As to weight gain, negative results were obtained with 750 FTU phytase/ $\mathrm{kg}$ feed and higher $(p<0.01)$.

When studying dietary phytase inclusion and different phosphorus levels in 22- to 42-day-old broilers, Wu et al. (2004) and Viveros et al. (2002) observed positive weight gain results. However, these data cannot be compared with the results of the present study because the aforementioned trials did not consider the enzyme nutritional matrix when formulating the experimental diets.

Table 5 - Mean weight gain (WG), feed intake (FI), and feed conversion ratio (FCR) of 22- to 42-day-old broilers fed different phytase levels.

\begin{tabular}{lccc}
\hline & \multicolumn{3}{c}{ Performance parameters from 22 to $\mathbf{4 2}$ days of age } \\
\cline { 2 - 4 } Treatments & WG(g) & FI(g) & FCR(g/g) $)^{\mathbf{3}}$ \\
\hline Control & $1637 \mathrm{~A}$ & 3323 & $2.030 \mathrm{~B}$ \\
$250 \mathrm{FTU} / \mathrm{kg}$ & $1578 \mathrm{AB}$ & 3227 & $2.045 \mathrm{AB}$ \\
$500 \mathrm{FTU} / \mathrm{kg}$ & $1573 \mathrm{AB}$ & 3252 & $2.068 \mathrm{AB}$ \\
$750 \mathrm{FTU} / \mathrm{kg}$ & $1562 \mathrm{~B}$ & 3255 & $2.083 \mathrm{AB}$ \\
$1000 \mathrm{FTU} / \mathrm{kg}$ & $1536 \mathrm{~B}$ & 3203 & $2.085 \mathrm{~A}$ \\
$\mathrm{~F}$ value1 & $4.84^{*}$ & $2.30 \mathrm{~ns}$ & $3.44^{*}$ \\
CV $(\%)$ & 2.62 & 2.24 & 1.52 \\
\hline
\end{tabular}

Means followed by different letters in the same column are significantly different $(p<0.05)$ by the test of Tukey. 1 - ns - not significant; ** - significant $(p<0.01)$. 2 Linear effect of phytase level: $y=1621.2943-0.0869 x ;\left(R^{2}=85.82\right)$. 3 Linear effect of phytase level: $y=2.0330+0.000058 x ;\left(R^{2}=94.54\right)$

Table 6 presents performance and production parameter means for the entire experimental period
Effect of Dietary Phytase Suplementation on the Performance, Bone Densitometry, and Phosphorus and Nitrogen Excretion of Broilers

(1-42 days of age). Weight gain, feed intake, and feed conversion ratio were significantly influenced $(p<0.01)$ by dietary phytase level. The polynomial regression of the analysis of variance showed linear effects on weight gain ( $\left.y=2341.3803-0.1461 x, R^{2}=96.03\right)$, feed conversion ratio $\left(y=1.8433+0.00007 x ; R^{2}=98.69\right)$, and production efficiency index ( $y=292.077-0.0266 x$; $\left.R^{2}=85.76\right)$. These results indicate that, when phytase was added to the feeds, weight gain and production efficiency index declined, and feed conversion ratio worsened. An optimal phytase level was not achieved for these parameters. The test of Tukey at $5 \%$ probability showed that the different phytase feed inclusion levels tested significantly influenced $(p<0.01)$ weight gain, feed conversion ratio, and production efficiency index, and that there was no effect ( $p>0.05$ ) on feed intake or livability. It was also the performance observed with the dietary addition of up to 250 FTU de phytase $/ \mathrm{kg}$ feed was similar to that of the control treatment.

\begin{tabular}{|c|c|c|c|c|c|}
\hline \multirow[t]{2}{*}{ Treatments } & \multicolumn{5}{|c|}{ Performance parameters from 1 to 42 days of age } \\
\hline & WG(g) $)^{2}$ & $\mathrm{FI}(\mathrm{g})$ & $\mathrm{FCR}(\mathrm{g} / \mathrm{g})^{3}$ & $\mathrm{~L}(\%)$ & PEI4 \\
\hline Control & $2355 \mathrm{~A}$ & 4340.64 & $1.843 \mathrm{~B}$ & 97.43 & $296 \mathrm{~A}$ \\
\hline $250 \mathrm{FTU} / \mathrm{kg}$ & $2289 A B$ & 4253.42 & $1.859 A B$ & 96.85 & $284 A B$ \\
\hline $500 \mathrm{FTU} / \mathrm{kg}$ & $2261 \mathrm{BC}$ & 4258.11 & $1.883 A B$ & 95.32 & $272 B$ \\
\hline $750 \mathrm{FTU} / \mathrm{kg}$ & $2239 \mathrm{BC}$ & 4262.47 & $1.904 \mathrm{~A}$ & 97.43 & $272 B$ \\
\hline $1000 \mathrm{FTU} / \mathrm{kg}$ & $2191 \mathrm{C}$ & 4208.42 & $1.898 \mathrm{~A}$ & 98.44 & $268 B$ \\
\hline $\mathrm{F}$ value ${ }^{1}$ & $8.64 * *$ & $1.99 \mathrm{~ns}$ & $5.07 * *$ & $1.21 \mathrm{~ns}$ & $5.73 * *$ \\
\hline CV (\%) & 2.17 & 1.94 & 1.49 & 2.63 & 4.17 \\
\hline
\end{tabular}

Means followed by different letters in the same column are significantly different $(p<0.05)$ by the test of Tukey. 1 - ns - not significant $; * \star-$ significant $(p<0.01)$. 2 Linear effect of phytase level: $y=2341.3803-0.1461 x ;\left(R^{2}=96.03\right)$. 3 Linear effect of phytase level: $y=1.8433+0.00007 x ;\left(R^{2}=98.69\right)$. 4 Linear effect of phytase level: $y=292.077-0.0266 x ;\left(R^{2}=85.76\right)$

When levels higher than 500 FTU phytase $/ \mathrm{kg}$ feed were added to the feeds, weight gain and production efficiency index were lower as compared to the control treatment. As to feed conversion ratio, the worst results were obtained when 750 and 1000 FTU phytase/kg feed were included.

The results obtained for the total rearing period showing that increasing phytase levels had negative effects on performance parameters are different from literature results (Tejedor et al., 2001; Lan et al., 2002; Wu et al., 2004). However, in literature, phytase nutritional matrix results were not considered in the formulation of the experimental diets, and therefore 


\section{Assuena V, Junqueira OM, Duarte KF, Laurentiz AC, Filardi RS, Sgavioli S}

only the effects of phytase on the availability of phytic phosphorus and of the other nutrients bound to the phytate molecule were evaluated.

Table 7 shows mean bone density results of 1 - to 21 -day-old broilers. There was a linear effect $(p<0.05)$ of phytase dietary level on all evaluated bone segments, indicating that bone density decreased as phytase level increased. The inclusion of 250 FTU phytase/kg feed and no phytase supplementation (control treatment) promoted the best results.

Onyango et al. (2004) evaluated the inclusion of phytase in feeds based on corn and soybean meal with reduced phosphorus content in starter broilers, and observed that bone density, bone mineral content, bone strength, and ash percentage were positively influenced by dietary phytase supplementation.

Most studies that correlate dietary phytase inclusion with phosphorus availability and bone deposition express their results as bone ash and phosphorus percentage and as bone strength (Banks et al., 2004; Payne et al., 2005; Pérsia \& Saylor, 2006 e Martinez et al., 2006), and suggest that the inclusion of phytase in diets with different available phosphorus levels promote higher ash content or tibia strength.

\begin{tabular}{|c|c|c|c|}
\hline \multirow[t]{2}{*}{ Treatments } & \multicolumn{3}{|c|}{ Bone density from 1 to 21 days of age } \\
\hline & $\begin{array}{l}\text { Proximal epiphysis } \\
(\mathrm{mm} \mathrm{Al})^{2}\end{array}$ & $\begin{array}{l}\text { Diaphysis } \\
(\mathrm{mm} \mathrm{Al})^{3}\end{array}$ & $\begin{array}{l}\text { Distal epiphysis } \\
(\mathrm{mm} \mathrm{Al})^{4}\end{array}$ \\
\hline Control & $1.8944 A B$ & $2.3677 \mathrm{~A}$ & $1.5317 \mathrm{~A}$ \\
\hline $250 \mathrm{FTU} / \mathrm{kg}$ & $1.7356 \mathrm{AB}$ & $1.9454 A B$ & $1.2577 \mathrm{~B}$ \\
\hline $500 \mathrm{FTU} / \mathrm{kg}$ & $2.0585 \mathrm{~A}$ & $14 A B$ & $1.5065 \mathrm{~A}$ \\
\hline $750 \mathrm{FTU} / \mathrm{kg}$ & $1.6042 \mathrm{~B}$ & $1.8209 \mathrm{~B}$ & $1.1671 \mathrm{~B}$ \\
\hline $1000 \mathrm{FTU} / \mathrm{kg}$ & $1.6660 A B$ & $1.8298 \mathrm{~B}$ & $1.1885 B$ \\
\hline F value ${ }^{1}$ & $3.53^{*}$ & $3.42 *$ & $2.58^{*}$ \\
\hline CV $(\%)$ & 17.31 & 19.50 & 26.01 \\
\hline
\end{tabular}

Means followed by different letters in the same column are significantly different $(p<0.05)$ by the test of Tukey. 1 - ns - not significant ; ** significant $(p<0.01) .2$ - Linear effect of phytase level: $y=1.9127$ 0.00024x; $\left(R^{2}=25.40\right) .3$ - Linear effect of phytase level: $y=2.2557-$ $0.00048 x ;\left(R^{2}=68.25\right) .4$ - Linear effect of phytase level: $y=1.4860$ $0.0003 x ;\left(R^{2}=48.85\right)$.

Mean bone densities of 22- to 42-day old broilers presented in Table 8 show a quadratic effect $(p<0.01)$ of phytase dietary inclusion on the bone density of the studied segments of the tibiotarsal bone. Proximal epiphysis bone density decreased $(y=2.2897-0.00157 x$ $\left.+0.000001 x^{2} ; R^{2}=67.92\right)$ up the level of 785 FTU, with a minimum density of $1.673 \mathrm{~mm} \mathrm{Al}$, whereas above 785 FTU, this value increased. In the diaphysis $(y=2.1621$ $\left.0.00195 x+0.000002 x^{2} ; R^{2}=87.25\right)$, the minimum value of $1.687 \mathrm{~mm}$ Al was obtained with the addition of 488
Effect of Dietary Phytase Suplementation on the Performance, Bone Densitometry, and Phosphorus and Nitrogen Excretion of Broilers
FTU phytase, above which this value increased. In the distal epiphysis $\left(y=1.8051-0.0021 x+0.000002 x^{2} ; R^{2}=\right.$ 63.00), the inclusion of up to 525 FTU phytase determined reducing values, with the lowest at $1.234 \mathrm{~mm} \mathrm{Al}$; above 525 FTU phytase, the results obtained increased.

Catala-Gregori et al. (2006) observed that birds fed diets containing different total phosphorus levels and supplemented with phytase presented lower bone ash percentage.

\begin{tabular}{|c|c|c|c|}
\hline \multirow{2}{*}{${ }^{\text {Treatments }}$} & \multicolumn{3}{|c|}{ Bone density from 22 to 42 days of age } \\
\hline & $\begin{array}{l}\text { Proximal epiphysis } \\
(\mathrm{mm} \mathrm{Al})^{2}\end{array}$ & $\begin{array}{l}\text { Diaphysis } \\
(\mathrm{mm} \mathrm{Al})^{3}\end{array}$ & $\begin{array}{c}\text { Distal epiphysis } \\
(\mathrm{mm} \mathrm{Al})^{4}\end{array}$ \\
\hline Control2.3556 & 2.2274 & 1.9164 & \\
\hline $250 \mathrm{FTU} / \mathrm{kg}$ & 1.8357 & 1.6669 & 1.1824 \\
\hline $500 \mathrm{FTU} / \mathrm{kg}$ & 1.7429 & 1.7441 & 1.2006 \\
\hline $750 \mathrm{FTU} / \mathrm{kg}$ & 2.0171 & 2.1942 & 1.5058 \\
\hline $1000 \mathrm{FTU} / \mathrm{kg}$ & 1.8748 & 2.2707 & 1.4196 \\
\hline F value1 & $5.57 * *$ & $8.09 * *$ & $9.81 * *$ \\
\hline CV $(\%)$ & 16.34 & 15.97 & 20.82 \\
\hline
\end{tabular}

$1 * *$ - significant $(p<0.01) .2$ - Quadratic effect of phytase level: $y=$ 2.2897-0.00157x+0.000001 $x^{2} ;\left(R^{2}=67.92\right) .3$ - Quadratic effect of phytase level: $y=2.1621-0.00195 x+0.000002 x^{2} ;\left(R^{2}=87.25\right) .4$ - Quadratic effect of phytase level: $y=1.8051-0.0021 x+0.000002 \times 2 ;\left(R^{2}=63.00\right)$.

Table 9 shows mean quantitative and qualitative traits of the excreta of broilers. Data analyses detected a significant linear effect of phytase levels $(p<0.01)$ only in ingested ( $y$ $\left.=4.22-0.0008 x ; R^{2}=92.60\right)$ and excreted $(y=3.1347$ $0.0011 x ; R^{2}=94.90$ ) phosphorus levels, indicating that ingested and excreted phosphorus percentages decreased as dietary phosphorus level increased. Possibly there was a higher utilization of minerals when phytase was included at higher levels, decreasing excreta mineral content. On the other hand, dietary phytase levels did not influence the other studied traits ( $p>0.05)$.

\begin{tabular}{|c|c|c|c|c|c|c|}
\hline \multicolumn{7}{|c|}{ Treatments Excreta quantitative and qualitative characteristics } \\
\hline & $\overline{\mathrm{DMI}(\mathrm{g})}$ & $\mathrm{PI}(\mathrm{g})^{2}$ & $\mathrm{NI}(\mathrm{g})$ & DME(g) & $\mathrm{PE}(\mathrm{g})^{3}$ & NE(g) \\
\hline Control & 648 & $4.14 \mathrm{~A}$ & 20.65 & 173 & $3.06 \mathrm{~A}$ & 10.98 \\
\hline $250 \mathrm{FTU} / \mathrm{kg}$ & 640 & $4.03 \mathrm{~A}$ & 21.13 & 162 & $2.84 \mathrm{AB}$ & 10.76 \\
\hline $500 \mathrm{FTU} / \mathrm{kg}$ & 659 & 3.89 A & 20 & 182 & $2.70 \mathrm{AB}$ & .82 \\
\hline $750 \mathrm{FTU} / \mathrm{kg}$ & 685 & $3.70 A B$ & 21.31 & 188 & $2.34 \mathrm{BC}$ & 11.14 \\
\hline $1000 \mathrm{FTU} / \mathrm{kg}$ & 659 & $3.29 \mathrm{~B}$ & 22.52 & 185 & $1.88 \mathrm{C}$ & 11.80 \\
\hline $\mathrm{F}_{\text {value }}{ }^{1}$ & $0.57 \mathrm{~ns}$ & 6.34 ** & $1.35 \mathrm{~ns}$ & $2.51 \mathrm{~ns}$ & $14.77^{* *}$ & $0.22 \mathrm{~ns}$ \\
\hline CV (\%) & 8.41 & 8.52 & 8.04 & 9.66 & 11.48 & 7.51 \\
\hline
\end{tabular}

Means followed by different letters in the same column are significantly different $(p<0.05)$ by the test of Tukey. 1 - ns - not significant ; ** significant $(p<0.01)$. 2 - Linear effect of phytase level: $y=4.22$ $0.0008 x_{;}\left(R^{2}=92.60\right) .3$ - Linear effect of phytase level: $y=3.1347-$ $0.0011 x ;\left(R^{2}=94.90\right)$. DMI - dry matter ingestion, DME - dry matter excretion; PI - phosphorus ingestion, NI - nitrogen ingestion; PE phosphorus excretion, NE - nitrogen excretion. 


\section{Assuena V, Junqueira OM, Duarte KF, Laurentiz AC, Filardi RS, Sgavioli S}

When the control treatment phosphorus ingestion and excretion results were compared to the other treatments, phosphorus ingestion reductions of approximately 3, 6, 11, and $21 \%$ were observed, with consequent decreases in phosphorus excretion of 7 , 12,23 , and $39 \%$. The highest level of phytase inclusion resulted in the lowest phosphorus excretion $(p<0.01)$, which is beneficial for the environment. However, when phytase was included in levels higher than $250 \mathrm{FTU} / \mathrm{kg}$ feed, broiler performance was compromised.

\section{CONCLUSIONS}

The inclusion of 250 FTU phytase/kg feed ensured good broiler performance; however, above this level, phytase had a negative impact on live performance and bone development. The availability of nutrients in the commercial product, as indicated by the manufacturer, may have determined these results, suggesting that the product nutritional matrix should be reviewed, and the need of further studies with the product

\section{REFERENCES}

Angel R, Saylor WW, Mitchell AD. et al. Effect of dietary phosphorus, phytase, and 25 - hydroxycholecalciferol on broiler chicken bone mineralization, litter phosphorus, and processing yields. Poultry Science 2006; 85:1200-1211.

Banks KM, Thompson KL, Jaynes P. et al. The effect of copper on the efficacy of phytase, growth, and phosphorus retention in broiler chicks. Poultry Science 2004; 83:1335-1341.

Borges FMO. Utilização de enzimas em dietas avícolas. Caderno Técnico da escola de Veterinária da UFMG 1997; (20):5-307.

Catalá-Gregori P, García V, Hernández F. et al. Response of broilers to feeding low - calcium and phosphorus diets plus phytase under different environmental conditions: Body weight and tibiotarsus mineralization. Poultry Science 2006; 85:1923-1931.

Conte AJ, Teixeira AS, Fialho ET. et al. Efeito da fitase e xilanase sobre o desempenho e as características ósseas de frangos de corte alimentados com dietas contendo farelo de arroz. Revista Brasileira de Zootecnia 2003; 32(5):1147-1156.

Denbow DM, Ravindran V, Konergay ET. et al. Improving phosphorus availability in soybean meal for broilers by supplemental phytase. Poultry Science 1995; 74:1831-18425.

Lan GQ, Abdullah N, Jalaludin S. et al. Efficacy of supplementation of a phytase - producing bacterial culture on the performance and nutrient use of broiler chickens fed corn - soybean meal diets. Poultry Science 2002; 81:1522-1532.
Effect of Dietary Phytase Suplementation on the Performance, Bone Densitometry, and Phosphorus and Nitrogen Excretion of Broilers
Louzada MJQ. Otimização da técnica de densitometria óptica em imagens radiográficas de peças ósseas. Estudos in vitro [tese]. Campinas (SP): Universidade Estadual de Campinas; 1994.

Martinez-Amezcua C, Parsons CM, Baker DH. Effect of microbial phytase and citric acid on phosphorus bioavailability, apparent metabolizable energy, and amino acid digestibility in distillers dried grains with solubles in chicks. Poultry Science 2006; 85:470-475.

Onyango EM, Bedford MR, Adeola $\mathrm{O}$. The yeast production system in which Escherichia coli phytase is expressed may affect growth performance, bone ash, and nutrient use in broiler chicks. Poultry Science 2004; 83:421-427.

Payne RL, Lavergne TK, Southern LL. A comparison of two sources of phytase in liquid and dry forms in broilers. Poultry Science 2005; 84:265-272.

Persia M E, Saylor WW. Effects of broiler strain, dietary nonphytate phosphorus, and phytase supplementation on chick performance and tibia ash. Journal Applied Poultry Research 2006; 15:72-81.

Qian H, Veit HP, Konergay ET. et al. Effects of supplemental phytase and phosphorus on histological and other tibial bone characteristics and performances of broilers fed semi-purified diets. Poultry Science 1996; 75: 618-626.

Rostagno HS. et al. Composição de alimentos e exigências nutricionais: tabelas brasileiras para aves e suínos. 2. ed. Viçosa: UFV; 2005. p.186.

SAS INSTITUTE SAS. System for Microsoft Windows, Release 6.12. Cary, NC; 2002.

Silva DJ. Análise de alimentos: métodos químicos e biológicos. 2.ed. Viçosa, MG: Universidade Federal de Viçosa; 1990.

Tejedor AA, Albino LFT, Rostagno HS. et al. Efeito da adição da enzima fitase sobre o desempenho e a digestibilidade ileal de nutrientes. Revista Brasileira Zootecnia 2001; 30:802-808.

Viveros A, Brenes A, Arija I. et al. Effects of microbial phytase supplementation on mineral utilization and serum enzymes activities in broiler chicks fed different levels of phosphorus. Poultry Science 2002; 81:1172-1183.

Wu YB, Ravindran V, Hendriks WH, Morel PCH, Pierce J. Evaluation of a microbial phytase, produced by solid state fermentation, in broiler diets. Influence on performance, toe ash contents, and phosphorus equivalency estimates. Journal Applied Poultry Research 2004; 13:373-383. 